\title{
振動電磁気力による濃度境界層厚みの低減
}

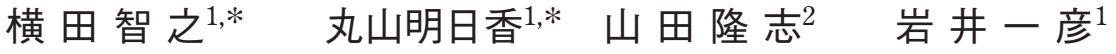 \\ ${ }^{1}$ 北海道大学大学院工学院 \\ 2名古屋市工業研究所
}

J. Japan Inst. Met. Mater. Vol. 81, No. 11 (2017), pp. 516-521

(C) 2017 The Japan Institute of Metals and Materials

\section{Decrease of Concentration Boundary Layer Thickness by Using Vibrating Electromagnetic Force}

\author{
Tomoyuki Yokota ${ }^{1, *}$, Asuka Maruyama ${ }^{1, *}$, Takashi Yamada ${ }^{2}$ and Kazuhiko Iwai ${ }^{1}$ \\ ${ }^{1}$ Faculty of Engineering, Hokkaido University, Sapporo 060-8628 \\ ${ }^{2}$ Nagoya Municipal Industrial Research Institute, Nagoya 456-0058
}

\begin{abstract}
For clarification of vibrating electromagnetic force effect on concentration boundary layer thickness formed near solid-liquid interface, a metal copper working as an anodic electrode was dissolved into an electrolyte aqueous solution under the imposition of a vibrating electromagnetic force. For its excitation, a current composed of $\mathrm{DC}$ and $\mathrm{AC}$ components and a static magnetic field were simultaneously imposed on an electrolyte aqueous solution. Because the copper divalent ions concentration is related with brightness of the solution by Lambert-Beer law, brightness of the recorded data using a video camera was directly used for evaluation of the concentration boundary layer thickness formed near the anodic electrode. The concentration boundary layer thicknesses formed under the imposition of the DC current and the static magnetic field, under the imposition of the DC \& AC superimposing current without a static magnetic field, and under the imposition of the DC current without a static magnetic field were almost the same, while that formed under the imposition of the DC \& AC superimposing current and the static magnetic field was thinner in comparison with the other three conditions. Hydrodynamic instability induced by the vibrating electromagnetic force through a large velocity gradient when the DC \& AC superimposing current and the static magnetic field were imposed on the solution might be the reason of the thinner concentration boundary layer. This might be a new tool for controlling mass transfer rate in a concentration boundary layer. [doi:10.2320/jinstmet.J2017022]
\end{abstract}

(Received May 11, 2017; Accepted August 7, 2017; Published October 25, 2017)

Keywords: electromagnetic force, vibration, concentration boundary layer, direct observation, mass transfer, hydrodynamic stability

\section{1. 緒言}

鉄鋼業におけるスラグーメタル間界面反応や凝固など，高 温下での工業プロセスにおいて取り扱われる液一液反応や 固 - 液反応の多くは, 化学反応律速ではなく物質移動律速と なることが知られている，例えば，スラグー溶融金属間の化 学反応の多くは液一液界面, 固 - 液界近傍に形成される濃度 境界層内の物質移動律速となる ${ }^{1,2)}$. また, めっきや電解研磨 などの金属表面処理プロセスでも, 生産性向上の観点から電 解速度の高速化が望まれるが, その場合には濃度境界層 (拡散 層)における生成物質や反応物質の除去速度, 供給速度が電極 反応速度に影響する条件 ${ }^{3)}$, すなわち, 濃度境界層(拡散層) の物質移動が律速段階となる条件で操作を行うことになる.

濃度境界層内での物質移動はフイックの法則 ${ }^{4)}$ で記述され る通り, 溶質濃度勾配と拡散係数の積に比例する. 拡散係数 は物性值なので能動的な制御は困難であるが, 濃度境界層厚 みを通して溶質の濃度勾配は制御可能である。 そこで, 従来, 固液界面近傍の速度勾配が急な領域の厚みを低減することで

* 北海道大学大学院生 (Graduate Student, Graduate School of Engineering, Hokkaido University)
濃度境界層厚みを減少させてきた．鉄鋼精錬プロセスでは, 化学反応を利用した溶鋼中の不純物除去行程などで機械攪 拌 $^{5)}$ ，ガス吹込み ${ }^{6)}$ による攪拌，電磁攪挥 ${ }^{7}$ などが行われてお り，溶鋼全体にわたる流動が誘起されている．めっきプロセ スにおいても，磁場を利用した液相攪拌に関する研究が行わ れてきている ${ }^{8,9)}$. 例えば, 山田らは, アルミニウムとマンガ ンの共析物の溶融塩電析において, 表面に光沢のある良好な 電析層を得るための上限電流密度を磁場印加によって増加さ せるとともに，増加の原因は磁場印加に起因する強制対流で あると結論づけている9)。しかしながらあまりに強攪拌する と, 反応速度向上という利点ばかりではなく, 久点が顕在化 してくる，例えば，鉄鋼プロセスでは，流速の過増加による スラグの巻き込みに起因する品質低下 ${ }^{10)}$ や耐火物の溶損が問 題となるため, 更なる反応速度の向上には別の手法が必要と なる。一方, 物質移動律速条件下での反応速度増大に求めら れることは, 濃度境界層における物質移動の高速化であり, 必ずしもバルク全体にわたっての流動を利用して濃度境界層 を薄くする必要はない. 我々は, 反応の高効率化・高速化の ために, 反応界面近傍での局所的な流動誘起を提案する. 従 来の攪拌は, 濃度境界層内における濃度勾配を大きくするこ とで拡散による物質移動を促進しているが, ここで提案する 
方法は濃度境界層内での物質移動を, 拡散ばかりではなく局 所的な流動をも利用して促進しようとするものである. 従っ て，強攪拌しなくとも物質移動の促進が期待される．局所的 な流動誘起の駆動力は外力の空間的不均一分布であり, これ を固液界面近傍の液相に与えるためのツールとして振動に着 目した。一方，電磁気力は連続鋳造などの鉄鋼プロセスで利 用されているとともに，めっき，電解研磨などの通電を伴う 金属表面処理プロセスにおいては，外部から磁場を印加する のみでこれを励起可能である。従って, 振動励起の外力とし て電磁気力を採用することとした.

本研究では, 振動電磁気力が固液界面近傍の濃度境界層厚 みに及ぼす影響を解明するために, 静磁場印加しながら, 直 流成分と交流成分とを重㽝した電流を電解水溶液へ通電する ことで, 振動電磁気力を励起させた. そして, アノードから 溶解される金属により形成される濃度境界層, および液相流 動の直接観察を行ったので，その結果について報告する.

\section{2. 実験装置および実験方法}

\section{1 実験装置と実験条件}

内寸で幅 $20 \mathrm{~mm} \times$ 奥行 $4 \mathrm{~mm}$ のアクリル製矩形容器の上部 と下部とに一対の銅板を設置して出来た, 内寸で幅 $20 \mathrm{~mm} \times$ 奥行 $4 \mathrm{~mm} \times$ 高さ $10 \mathrm{~mm}$ の空間へ $0.3 \mathrm{molL}^{-1} \mathrm{CuSO}_{4}+0.1 \mathrm{molL}^{-1}$ $\mathrm{H}_{2} \mathrm{SO}_{4}$ 水溶液を満たした。 その縦断面図を Fig. 1 に示す。実 験を開始する前の水溶液の $\mathrm{pH}$ は約1.0であった。 下側に設置 した銅板がアノード，上側に設置した銅板がカソードとなる ように, それらと電源とを繋いだ。矩形容器角部近傍の流れ は底面と平行にならない, そこで, 容器両側壁から中央部に 向かって $5 \mathrm{~mm}$ の範囲を $100 \mu \mathrm{m}$ 程度の厚さで銅板を絶縁被 覆して, 残りの部分をアノードとした. このアノード両端の マスキングによって, アノード両端での電流集中が起きるこ とが予測される。 そこで，電流集中の影響がないと考えられ るアノードの中心における濃度境界層を観察することとした.

電流印加は, 以下の 2 条件とした。

· $15 \mathrm{~mA}$ の直流電流のみの通電 (以降, DC 通電と表記する)

- $15 \mathrm{~mA}$ の直流電流と $0.5 \mathrm{~Hz}, 30 \mathrm{~mA}_{\mathrm{p}-\mathrm{p}}$ の交流電流の重畳 通電 (以降, $\mathrm{DC}+\mathrm{AC}$ 通電と表記する)

また，それぞれの通電条件に対して，静磁場印加あるいは 静磁場無印加の二通りで実験を行った。すなわち, 実験は 4 条件で行った．静磁場の向きは，Fig. 1 の紙面に垂直で手前 から奥の向きであり, アノード近傍中央で $0.25 \mathrm{~T}$, カソード 近傍中央で $0.20 \mathrm{~T}$ として,アノード近傍の磁場強度をカソー ド近傍の磁場強度より強くすることで流動を誘起した。なお,

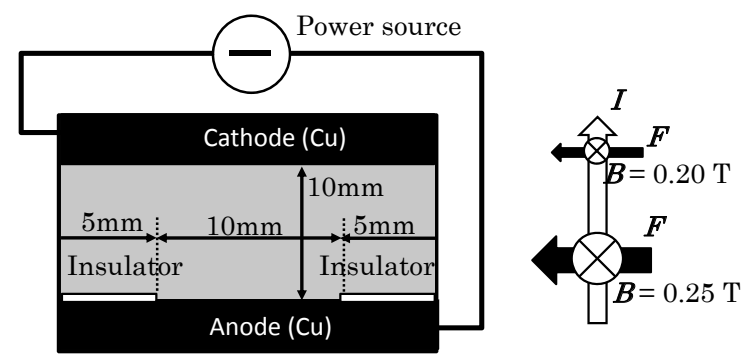

Fig. 1 Vertical cross section of experimental apparatus.
電流 $\boldsymbol{I}$, 静磁場 $\boldsymbol{B}$, 電磁気力 $\boldsymbol{F}$ の向きは Fig. 1 に示す通りで ある。

\section{2 流動の観察方法}

直径 $80 \mu \mathrm{m}$, 密度 $1055 \mathrm{kgm}^{-3}$ のポリスチレン粒子をトレー サーとして水溶液中に加えて, その運動から電解液の流動を 推定した．粒子が流動に追従するか否かの指標となる Stokes 数 Stk は以下の式で与えられる11).

$$
\mathrm{Stk}=\frac{\rho_{p} d^{2} U_{L}}{4 \eta L}
$$

ここで, $\rho_{p}$ は粒子密度, $d$ は粒子直径, $U_{L}$ は代表流速, $\eta$ は 流体の粘性係数, $L$ は流れの代表長さである.

今回の実験系の值である, $\rho_{p}=1055 \mathrm{kgm}^{-3}, d=8.0 \times 10^{-5} \mathrm{~m}$, $\eta=1.0 \times 10^{-3} \mathrm{kgm}^{-1} \mathrm{~s}^{-1}, \quad L=1.0 \times 10^{-4} \mathrm{~m}, \quad U=1.0 \times 10^{-3} \mathrm{~ms}^{-1}$ を式 ( 1 ) に代入すると, Stokes 数は

$$
\text { Stk }=0.017 \ll 1
$$

となり，粒子は液体流動に追従することとなる.

流体中の固体球が密度差により沈降あるいは浮上するとき の終末速度 ${ }^{12)}$ は次式で与えられる。

$$
u_{t}=\frac{d^{2} \Delta \rho g}{18 \eta} \quad(\operatorname{Re}<1)
$$

ここで, $u_{t}$ は粒子の終末速度, $\Delta \rho$ は粒子と流体の密度差, $g$ は重力加速度である。

流体の密度は約 $1046 \mathrm{kgm}^{-3}$ と推定されるので, $\Delta \rho=9 \mathrm{kgm}^{-3}$ とすれば, $u_{t}=31 \mu \mathrm{ms}^{-1}$ となる. よって, 液相の流速が粒子 の終末(沈降)速度より十分速ければ，これを無視しうる。ま た, 遅くとも, 沈降挙動を考慮することで大まかな流速は推 定可能である. なお, このときのレイノルズ数は $\mathrm{Re}=2.5 \times$ $10^{-3}$ であり, 式 ( 3 )の適用範囲内である。以上より, 概ね卜 レーサーの挙動は流動を示すと言える. なお, 光源は photoron 社製の HVC-ULであり, photoron 社製の FASTCAM Mini UX50を用いて, 1 pixelが $22 \mu \mathrm{m} \times 22 \mu \mathrm{m}$ の精度で撮影を行っ た.また, 実験装置は光源から $2 \mathrm{~m}$ 程度離れており, 熱対流 の影響はない.

\section{3 濃度境界層の測定方法}

上述の通り, 今回の実験では光透過性を有する硫酸一硫酸 銅水溶液を用いた．銅をアノード電極として硫酸－硫酸銅水 溶液を電解した場合, その近傍に $\mathrm{Cu}^{2+}$ イオンの拡散層 (以後, 濃度境界層と記述する)が形成される. $\mathrm{Cu}^{2+}$ イオンは水溶液 中で青色に呈色するので, 拡散層は周囲のバルク液相よりも 濃い青色を示す. Lambert-Beerの法則 ${ }^{13)} に よ り$, その明度と $\mathrm{Cu}^{2+}$ イオン濃度とは正の相関があるので，ここでは明度によ り $\mathrm{Cu}^{2+}$ イオンの濃度を評価した。

明度の測定位置を Fig. 2 に示す.アノード表面の水平方向

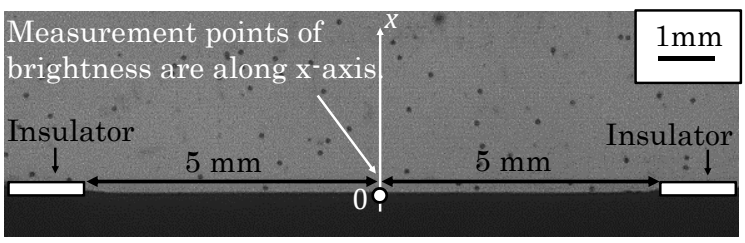

Fig. 2 Measurement points of brightness. 


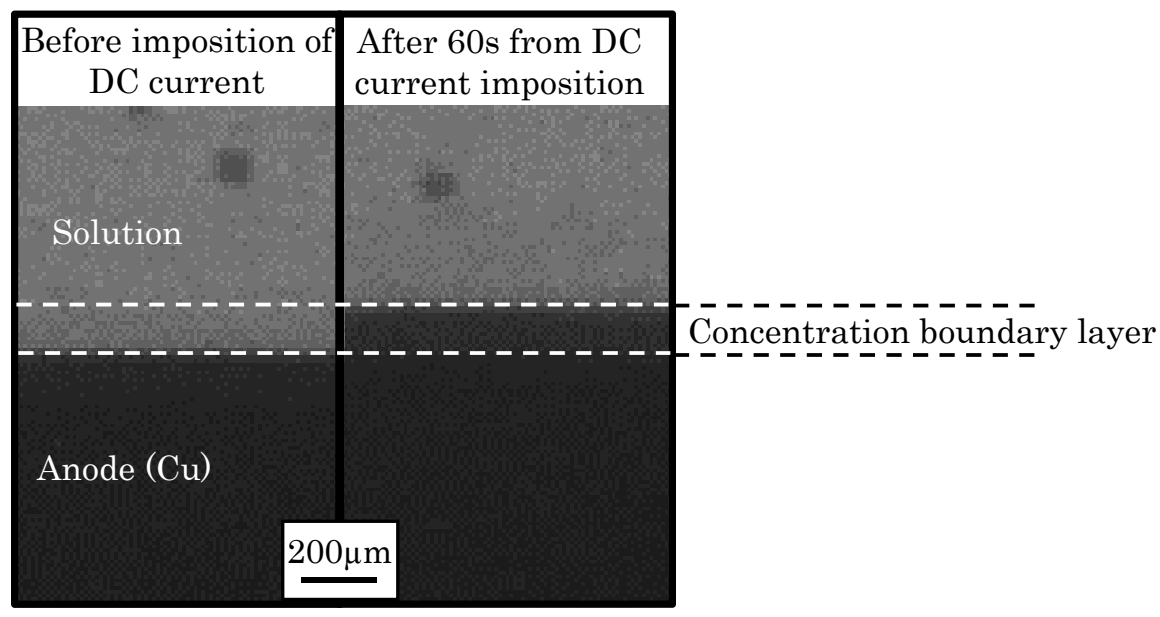

Fig. 3 Change of brightness by imposing current.

中央を原点，鉛直上向きを正として $x$ 軸を定義し，これに沿っ て 1 pixel $(22 \mu \mathrm{m} \times 22 \mu \mathrm{m})$ ずつ明度を測定した。この付近に 打ける通電前と通電後 $60 \mathrm{~s}$ の様子を比較した写真を Fig. 3 に 示す，実験条件は，静磁場無印加の DC 通電である。アノー ドから $\mathrm{Cu}^{2+}$ イオンが溶出するので, その近傍の水溶液の明度 が低下していることが分かる。この明度低下現象を観察し， 濃度境界層を評価した。

実験に先だって，通電により $\mathrm{Cu}^{2+}$ イオンがアノードから液 相へ溶出することで界面位置が移動する可能性について検討 した。 アノードの被覆されていない露出部の全面から一様に $\mathrm{Cu}^{2+}$ イオンが溶解すると仮定して, 実験に扔ける電流值, I= $15 \mathrm{~mA}$, 通電時間, $t=60 \mathrm{~s}$, アノード面積, $S=40 \mathrm{~mm}^{2}$ を用 いて，アノード界面高さ変化， $\Delta \mathrm{H}$ を求めると

$$
\Delta H=\frac{t \boldsymbol{I} M_{C u}}{2 F \rho_{c u} S}=0.83 \mu \mathrm{m}
$$

ただし，計算に際してファラデー定数 $F^{14)} 96500 \mathrm{Cmol}^{-1}$, 銅の原子量 $M_{C u}{ }^{15)}$ を $63.5 \mathrm{gmol}^{-1}$ ，固体銅の密度 $\rho_{C u}{ }^{15)}$ を 8930 $\mathrm{kgm}^{-3}$ とした.

この值は実験における明度測定の最小単位である 1 pixel $=22$ $\mu \mathrm{m} \times 22 \mu \mathrm{m}$ を大きく下回っている，そこで，通電前後のア ノード界面高さ変化は無視した。

\section{3. 実 験 結 果}

\section{$3.1 \mathrm{DC}$ 通電時に形成される濃度境界層に与える静磁場印加 の効果}

静磁場印加の有無によらず，通電によってアノードと液相 との界面から濃度境界層が形成され，時間経過に伴って成長 した．まず，液相の流動について述べる．静磁場無印加条件 では，特定の流動パターンは観察されずランダムな流れで あった。アノードから $200 \mu \mathrm{m}$ 程度離れた位置に打ける水平 方向流速は最大で $50 \mu \mathrm{ms}^{-1}$ であり, $600 \mu \mathrm{m}$ 以上離れた位置で の水平方向最大流速は $100 \mu \mathrm{ms}^{-1}$ 程度であった．静磁場印加 した場合, 電磁気力が励起されるので Fig. 4 に示すように容 器全体に渡っての定常的な循環流が観察された。アノード近 傍に扔ける水平方向の最大流速はアノードから離れるにつれ て徐々に増加し， $600 \mu \mathrm{m}$ あるいはそれ以上離れると $1200 \mu \mathrm{ms}^{-1}$

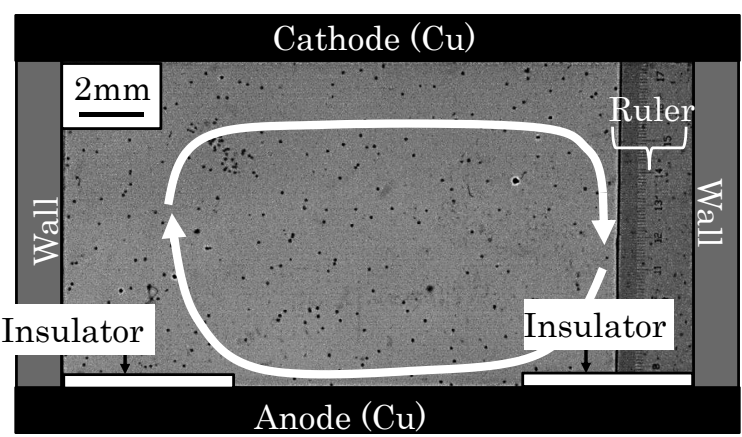

Fig. 4 Flow pattern under imposition of DC current with a static magnetic field.

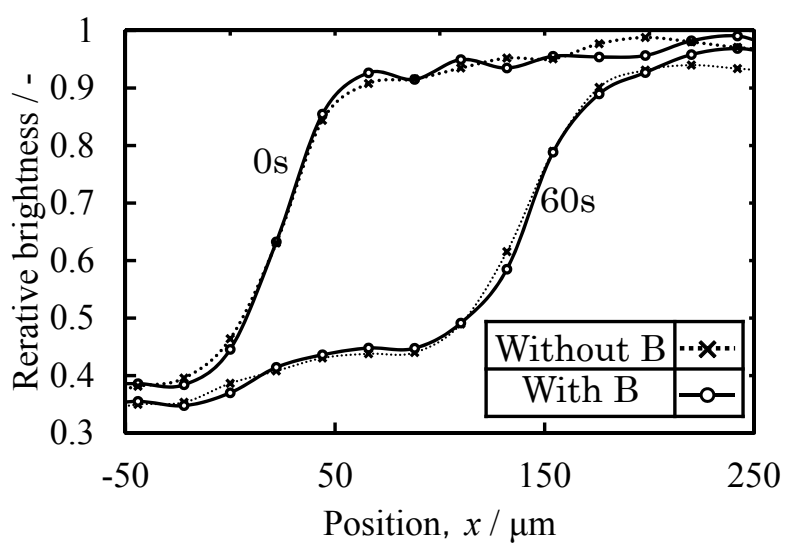

Fig. 5 Relative brightness distribution under imposition of DC current with or without a static magnetic field.

程度, その間の $200 \mu \mathrm{m}$ 程度離れた位置では $400 \mu \mathrm{ms}^{-1}$ 程度で あった。

静磁場印加，無印加のそれぞれの条件下で，DC 通電した ときの通電開始前 (以降，0 s と表記する) 㧍よび通電開始後60 秒後 (以降, $60 \mathrm{~s}$ と表記する)の相対明度分布を Fig. 5 に示す. 縦軸は本実験で用いた水溶液のバルク液相での明度を基準と して正規化した相対明度を表す。これ以降，正規化した相対 明度を単に明度と記す。横軸はアノード表面，すなわち固液 界面からバルク液相方向への距離， $x$ である。また，図中の 点線は静磁場無印加時の明度, 実線は静磁場印加時の明度を それぞれ示す． $0 \mathrm{~s}$ の明度であるが，磁場印加の有無によらず 
固液界面からバルク液相に向かって $50 \mu \mathrm{m}$ 程度の区間は徐々 に上昇している。 これは, 光源からの光路と固液界面とが完 全には平行ではないために, アノード最近傍の液相の明度に バラつきが生じたためであると考えられる。しかしながら， $50 \mu \mathrm{m}$ 以上離れると明度はほぼ一定となること, 実験中に観 察系の位置は変化しないのでこの影響に時間変化はないこと, 銅の溶出による固液界面位置の変化は無視できること, から $50 \mu \mathrm{m}$ 以下の領域でも通電開始からの時間経過による明度変 化の傾向を定性的に評価するには大きな支障はないと考えら れる。

磁場印加の有無にかかわらず $0 \mathrm{~s}$ の明度に対して $60 \mathrm{~s}$ の明 度は $0 \mu \mathrm{m}$ から $170 \mu \mathrm{m}$ 程度の範囲で低下した。すなわち, 濃 度境界層厚みは概略 $170 \mu \mathrm{m}$ である. 室温における $\mathrm{Cu}^{2+}$ イオ ン飽和時の明度を推定したところ, 約 0.65 となった．液相の 明度低下が $\mathrm{Cu}^{2+}$ イオン濃度の増大のみによるものであれば, 通電後であっても液相の明度はこの值以下にはならないが, $60 \mathrm{~s}$ の明度はそれよりも低い值を示す領域がある。この現象 についての詳細は別報16)に記している通り，アノード最近傍 において $\mathrm{Cu}^{2+}$ イオンの他に $\mathrm{Cu}$ 微粒子が生成し, この $\mathrm{Cu}$ 微 粒子が明度に影響を与えている可能性があると考えられる. $\mathrm{Cu}$ 微粒子が明度にどの程度の影響を及ぼすかは不明だが, $\mathrm{Cu}^{2+}$ イオン濃度が高いアノード最近傍のみで析出すると考え れば，その影響は固液界面からバルク液相へ向かうにした がって小さくなり，ある程度以上離れると無視できると考え られる. 静磁場印加, 無印加のそれぞれの $60 \mathrm{~s}$ における明度 がほぼ重なっていることから, 静磁場, すなわちそれによっ て引き起こされる流動は, 濃度境界層厚みおよび濃度プロ ファイルに影響を与えないことが分かる.

\section{2 静磁場無印加下で形成される濃度境界層に対する DC 通 電と $\mathbf{D C}+\mathbf{A C}$ 通電との差異}

静磁場無印加で $\mathrm{DC}+\mathrm{AC}$ 通電したときの流動は, DC 通電 と同様にランダムであり, アノードと液相との界面から $200 \mu \mathrm{m}$ 程度沖合で最大流速は $50 \mu \mathrm{ms}^{-1}$ 程度であった. 静磁場無印加 で $\mathrm{DC}$ 通電， あるいは $\mathrm{DC}+\mathrm{AC}$ 通電のときの $0 \mathrm{~s}$ ，および $60 \mathrm{~s}$ の明度分布を Fig. 6 に示す. 図中の破線は DC 通電の明度分 布を, 実線は $\mathrm{DC}+\mathrm{AC}$ 通電の明度分布をそれぞれ示す。なお, $\mathrm{DC}+\mathrm{AC}$ 通電の $60 \mathrm{~s}$ では, 交流の一周期である 2 秒間を 5 等

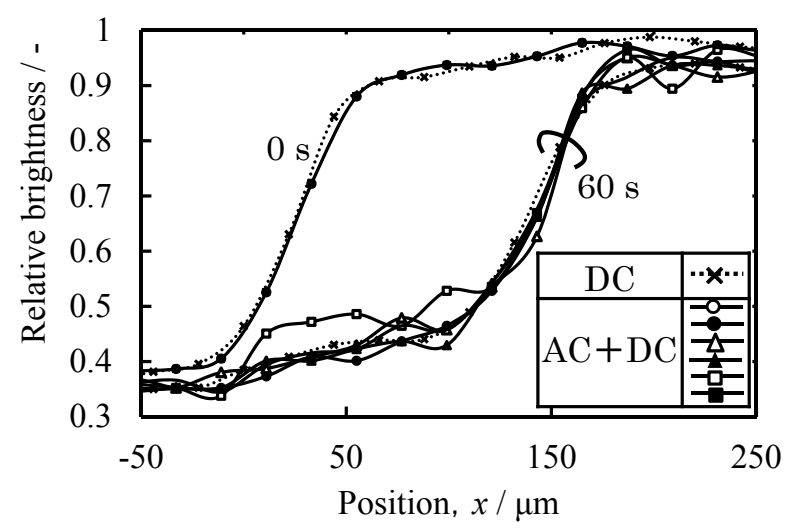

Fig. 6 Relative brightness distribution under imposition of DC current or DC $+\mathrm{AC}$ current without a static magnetic field.
分割した各時刻における明度を示している。 DC 通電, DC+ $\mathrm{AC}$ 通電のいずれも $0 \mathrm{~s}$ の明度に対して $60 \mathrm{~s}$ の明度は 0 170 $\mu \mathrm{m}$ 程度の範囲で低下しており, 両者はほぼ重なっているこ とから, 濃度プロファイルは同一であり, 濃度境界層厚みの 差は見られないことが分かる. また, $\mathrm{DC}+\mathrm{AC}$ 通電時には 70 $\mu \mathrm{m}$ 付近で明度が逆転している時間が存在するが, $\mathrm{Cu}^{2+}$ イオ ン濃度と密度とは正の相関があるので, 上部の密度が下部の 密度より大きくなる時間帯が存在することがわかった。

\section{3 静磁場印加下で形成される濃度境界層に対する $\mathrm{DC}$ 通電 と $\mathrm{DC}+\mathrm{AC}$ 通電との差異}

静磁場印加しつつ DC 通電したときの流動はすでに Fig. 4 に示した通り, 容器全体に渡っての定常的な循環流であった. 一方, $\mathrm{DC}+\mathrm{AC}$ 通電したときの流れは, Fig. 4 に示した静磁 場印加しつつ DC 通電したときの流動と類似しており, そこ に振動が加わったものであった. アノードから $200 \mu \mathrm{m}$ 程度 沖合で最大流速は $900 \mu \mathrm{ms}^{-1}$ 程度, 流速の最小值は $100 \mu \mathrm{ms}^{-1}$ 未満であった. この最大流速は, 静磁場印加しつつ DC 通電 したときの值である $400 \mu \mathrm{ms}^{-1}$ よりも 2 倍以上速い. $\mathrm{DC}+\mathrm{AC}$ 通電したときは, DC 通電したときに比べて大きな電磁気力 が作用する時間帯が存在するので, 壁近傍の液相まで流速が 増加したものと考えられる。一方, $600 \mu \mathrm{m}$ 程度離れた位置の 最大流速はおよそ $1200 \mu \mathrm{ms}^{-1}$ 程度であり, DC 通電したとき の值である $1200 \mu \mathrm{ms}^{-1}$ 程度と同程度である. すなわち, 静磁 場印加しつつ DC + AC 通電したときは, アノード近傍 $200 \mu \mathrm{m}$ 以下の領域において DC 通電したときよりも大きな速度勾配 が存在するが, $600 \mu \mathrm{m}$ 以上離れた流速には大差ないことがわ かった。

静磁場印加しつつ DC 通電, あるいは $\mathrm{DC}+\mathrm{AC}$ 通電したと きの $0 \mathrm{~s}$ および $60 \mathrm{~s}$ の明度分布をアノード中央に加えて, ア ノード右端から $1 \mathrm{~mm}$ の位置において測定した。それらの結 果を Fig. 7 に示す。なお, $\mathrm{DC}+\mathrm{AC}$ 通電の場合は 1 周期の平 均值を示している，通電開始前の明度分布は位置によらずほ ぼ同一である.アノード右端近傍は液相上部の $\mathrm{Cu}^{2+}$ イオン濃 度の希薄な液相が流れ込むにもかかわらず, DC 通電 $60 \mathrm{~s}$ 後 のアノード右端から $1 \mathrm{~mm}$ における濃度境界層は中央におけ る濃度境界層より厚くなった。これはアノード両端での電流 集中によるものと解釈される．同様の現象は $\mathrm{DC}+\mathrm{AC}$ 通電の 時も観察された。なお，アノード中央の濃度境界層が右端か

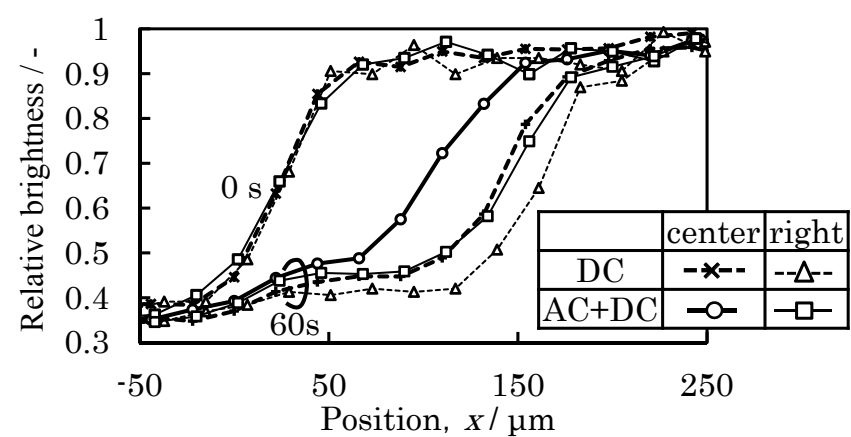

Fig. 7 Relative brightness distribution under imposition of DC current or DC $+\mathrm{AC}$ current with a static magnetic field measured at center or at $1 \mathrm{~mm}$ inside from right end of anode. 
ら $1 \mathrm{~mm}$ における濃度境界層より薄かったとの実験結果は, アノード右端近傍の高濃度液相の流れ込みがアノード中央で の濃度境界層に影響を与えないことを示唆しており, Fig. 5 で述べた， DC 通電時のアノード中央における濃度境界層に 対して流動は影響を及ぼさないことと整合性がある。また, 同一位置で濃度境界層厚みを比較すると, DC 通電に比べて $\mathrm{DC}+\mathrm{AC}$ 通電の場合は薄くなった。 すなわち, $\mathrm{DC}+\mathrm{AC}$ 通電 によりアノード近傍での $\mathrm{Cu}^{2+}$ イオン濃度が低下した. さら に，図が煩雑となるので示さなかったが， $\mathrm{DC}+\mathrm{AC}$ 通電時に は通電開始から $60 \mathrm{~s}$ において $70 \mu \mathrm{m}$ 付近で明度が逆転して いる時間帯がいずれの位置においても Fig. 6 と同様に観察さ れた。すなわち, 上部の密度が下部の密度より大きくなる時 間帯の存在がわかった.

以上をまとめると, AC 電流を DC 電流に重睍することで, ・濃度境界層厚みが低減したこと,

・濃度境界層内において, 液相上部の密度が下部より大きく なる時間帯が存在したこと，

・アノード中央近傍の速度勾配が大きくなったこと， がわかった。

\section{4. 考察}

静磁場印加しつつ $\mathrm{DC}+\mathrm{AC}$ 通電したときに濃度境界層厚み が減少したことから, この条件で局所攪汼が生じている可能 性が高い，通電による $\mathrm{Cu}^{2+}$ イオンの溶出は液相の密度を増加 させる. DC 通電のときに, この現象はアノード界面近傍か ら起きるが, $\mathrm{DC}+\mathrm{AC}$ 通電では溶出速度が周期的に変化する ので, 下部の密度よりも上部の密度のほうが大きくなること で流体力学的不安定性状態となり局所攪拌が誘起される可能 性がある. しかしながら, 静磁場無印加で DC + AC 通電した ときは濃度境界層厚みが減少しなかったので, 今回の濃度境 界層厚み減少は, 密度差が引き起こす流体力学的不安定性が 原因ではない.

濃度境界層厚みが減少した実験条件は，アノードと液相と の界面から $200 \mu \mathrm{m}$ 程度沖合での最大流速が $900 \mu \mathrm{ms}^{-1}$ 程度で あり, 他の 3 条件に比べて濃度境界層領域における速度勾配 が大きい時間帯が存在する。これにより流体内の微小擋乱が 増幅されて不安定状態が引き起こされ，局所攪拌につながっ た可能性がある。 そこで, 今回の実験条件で微少擋乱が増幅 されるのか否かについて検討した.

流体上部ほど低密度である密度分布, 水平面内で一方向に 運動しているものの流体上部ほど高速である速度分布を持つ, 無限に拡がった非圧縮性非粘性流体を考える、鉛直方向位置 $z=0$ で密度は $\rho_{0}$, 速度はゼロとして, それらの分布を以下 の式で与える。

$$
\begin{gathered}
\frac{\rho}{\rho_{0}}=\exp \left(-\frac{z}{h}\right) \quad(z>0) \\
\frac{U}{U_{0}}=\tanh \left(\frac{z}{d}\right) \quad(z>0)
\end{gathered}
$$

ここで, $d$ は速度分布の代表長さ, $h$ は密度分布の代表長さ, $U$ は速度, $U_{0}$ は代表速度, $\rho$ は密度, である.

このとき, 流体力学的に安定であるか, 不安定であるかは
式（７）に示すリチャードソン数，Jにより決定される。両者 の境界である中立曲線は, 中立安定の波長, $\lambda$ の関数として 式( 8 ) で与えられる17).

$$
\begin{gathered}
J=\frac{g}{h} \frac{d^{2}}{U_{0}^{2}}(>0) \\
J=d^{2}\left(\frac{2 \pi}{\lambda}\right)^{2}\left(1-d^{2}\left(\frac{2 \pi}{\lambda}\right)^{2}\right)
\end{gathered}
$$

ここで, $\mathrm{g}$ は重力加速度である.

安定領域, 不安定領域をリチャードソン数, J の関数とし て Fig. $8^{17)}$ に示す.リチャードソン数，J の值が 0.25 より大き ければ, 流体力学的に必ず安定であるが, 0.25 未満であれば, ある波長の範囲で流体力学的に不安定となる.

代表速度， $\mathrm{U}_{0}$ ，および密度分布の代表長さ， $\mathrm{h}$ の関数とし て, リチャードソン数, Jを求めた。 その際, 速度分布の代 表長さは $\mathrm{d}=100 \mu \mathrm{m}$ と一定值にした，その結果を Fig. 9 に示 す。図中の一点鎖線は, 安定領域と不安定領域の境界である, リチャードソン数, $\mathrm{J}=0.25$ を示す. 右下がりの 3 本の直線は, それぞれ代表速度が $\mathrm{U}_{0}=10^{-3} \mathrm{~ms}^{-1}, 10^{-4} \mathrm{~ms}^{-1}, 10^{-5} \mathrm{~ms}^{-1}$ の きのリチャードソン数, Jを表す，代表速度， $\mathrm{U}_{0}$ にらすす，密 度分布の代表長さ，hが大きいとリチャードソン数，Jは小さ くなり, 安定領域から不安定領域へ遷移する。 また，代表速 度 $\mathrm{U}_{0}$ が大きいほど, 密度分布の代表長さ, $\mathrm{h}$ が小さな值でも 不安定領域となるので，不安定性が誘起されやすい，言い換 えると，たとえ下部の密度が大きくて重力エネルギーの観点 からは安定であっても, 上下の密度差が小さくて均一に近い ほど，また速度勾配が大きいほど流体力学的不安定が誘起さ れやすいことがわかる。このことは，濃度境界層厚みが減少 した条件である静磁場印加しつつ $\mathrm{DC}+\mathrm{AC}$ 通電したときに,

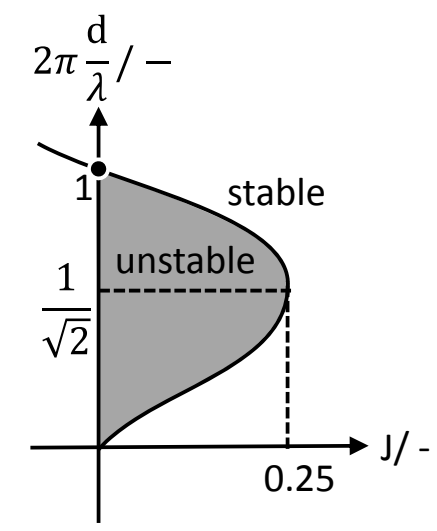

Fig. $8^{17)}$ Neutral stability as a function of Richardson number, J.

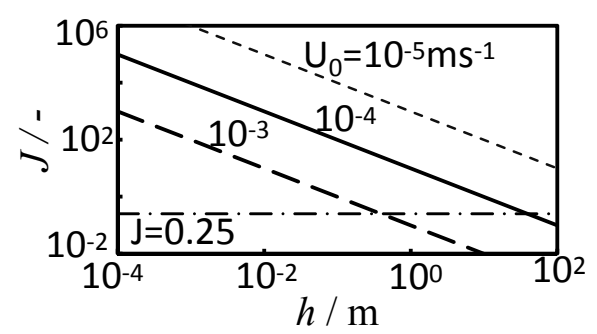

Fig. 9 Richardson number, $\mathrm{J}$ as a function of characteristic length for density, h, and relative density change in $100 \mu \mathrm{m}$. 


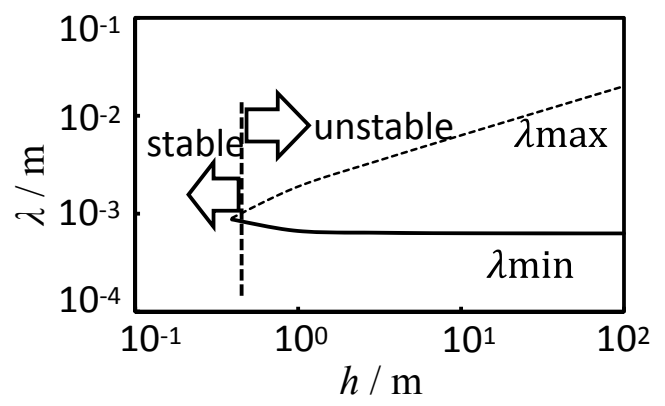

Fig. 10 Maximum and minimum wave length of instability as a function of characteristic length for density, $h$.

アノード表面からの距離が $200 \mu \mathrm{m}$ 程度での最大流速は約 900 $\mu \mathrm{ms}^{-1}$ であり，他の 3 条件に比べて最も速度勾配が大きかった ことと定性的に一致する. DC 通電時の最大流速は約 $400 \mu \mathrm{ms}^{-1}$ であったからこのときに不安定状態が引き起こされるには, 式 ( 7 ) から密度分布の代表長さが 5 倍 $\left((900 / 400)^{2} \fallingdotseq 5\right)$ 程度 大きい必要がある。なお, 静磁場印加しつつ $\mathrm{DC}+\mathrm{AC}$ 通電し たときに界面より $200 \mu \mathrm{m}$ 程度離れた位置で観測された最大 流速と類似の值である $1 \mathrm{mms}^{-1}$ を代表速度 $\mathrm{U}_{0}$, 速度分布の代 表長さを $\mathrm{d}=100 \mu \mathrm{m}$, とした場合, 流体力学的不安定が起こ りうる, 密度分布の代表長さの最小値は $\mathrm{h}=0.39 \mathrm{~m}$ と計算さ れる。このとき，式（５）から計算される密度の減少率は，鉛 直方向距離 $z=100 \mu \mathrm{m}$ に抒いて0.9997なので，鉛直方向にほ とんど密度差のない状態であれば，静磁場印加しつつ DC+ $\mathrm{AC}$ 通電した条件で, 流体力学的不安定が起こりうることが, 半定量的にも理解される.なお，アノードから $170 \mu \mathrm{m}$ 以上 離れた箇所で，上部の密度が下部のそれより大きな実験結果 が Fig. 7 等でみられるが，速度勾配が小さいため，今回考察 している流体力学的不安定は起きなかったものと考元られる.

次に，不安定性を波長の観点から考察した，先ほどと同じ $<1 \mathrm{mms}^{-1}$ を代表速度 $\mathrm{U}_{0}$, 速度分布の代表長さを $\mathrm{d}=100 \mu \mathrm{m}$, として, 不安定性が起こりうる最小波長 $\lambda$ min, 最大波長 $\lambda \max$ を式 $(7)$ より求めた。波長がこの両者の間であれば, 不 安定性が起こりうる. 計算結果を Fig. 10 に示す. h が大きく なるほど最小波長は小さくなる一方, 最大波長は大きくなる. 先ほどと同じく $\mathrm{h}=1 \mathrm{~m}$ とすれば, 最小波長は約 $670 \mu \mathrm{m}$, 最 大波長は約 $1.9 \mathrm{~mm}$ である。この程度の波長であれば, 今回 の実験系の寸法から考えて十分起こりうる波長である.

以上のことから, 静磁場印加しつつ $\mathrm{DC}+\mathrm{AC}$ 通電した条件 では, $\mathrm{Cu}^{2+}$ イオンの溶出速度が周期的に変化するので, 液相 密度はアノード近傍よりも上部のほうが大きくなる(あるいは ほぼ均一になる)領域, 時間帯が存在すること，アノード上部 で高流速となり速度勾配が大きくなる時間帯が存在すること, により流体力学的不安定が誘起されて濃度境界層が低減され たものと推測される。従って, 流体力学的不安定性を励起す る振動の印加は固液界面近傍の物質移動促進に有用なツール となり得る。

\section{5. 結言}

本研究では, 振動電磁気力が固液界面近傍の濃度境界層厚
みに及ぼす影響を解明するために, 直流電流への交流電流重 畳の有無, 静磁場印加の有無の組み合わせによる 4 条件にお いて，アノードから溶解される金属により形成される濃度境 界層，および液相流動の直接観察を行った。その結果，以下 の知見を得た

- 静磁場印加しつつ DC 通電, 静磁場無印加で DC + AC 通電, あるいは静磁場無印加で DC 通電したときの濃度境界層厚み はほぼ同一であった。

・静磁場印加しつつ $\mathrm{DC}+\mathrm{AC}$ 通電したときに観察された濃度 境界層は, 上記 3 条件で観察された濃度境界層厚みより薄く なった。このとき，アノード中央近傍の速度勾配は 4 条件の 中で最大であった.

・ DC + AC 通電したときは磁場印加の有無にかかわらず濃度 境界層内において, 液相上部の密度が下部より大きくなる時 間帯が存在した。

・液相下部の密度が大きくて重力エネルギーの観点からは安 定であっても，上下の密度差が小さくて均一に近いほど，ま た上下の速度勾配が大きいほど流体力学的不安定は誘起され やすいが，今回の 4 条件のうち，この不安定性が起きやすい 状態に最も近い実験結果となったのは, 静磁場印加しつつ $\mathrm{DC}+\mathrm{AC}$ 通電した条件であり, このとき濃度境界層厚みが低 減された

-今回の実験条件で発生しうる流体力学的不安定性の波長を 理論的に計算したところ，今回の実験装置で十分起きうる 1 $\mathrm{mm}$ 程度のオーダーであった。

以上のことから, 静磁場印加しつつ $\mathrm{DC}+\mathrm{AC}$ 通電した条件 では, 流体力学的不安定が誘起されて濃度境界層厚みが低減 されたものと推測される.

文献

1) M. Hirasawa, K. Mori, M. Sano, A. Hatanaka, Y. Shimatani and Y. Okazaki: Tetsu-to-Hagané 73(1987) 1343-1349.

2) M. Hirasawa, K. Mori, M. Sano, Y. Shimatani and Y. Okazaki: Tetsu-to-Hagané 73(1987) 1350-1357.

3) Y. Awakura: Journal of the Surface Finishing Society of Japan 61 (2010) 112-115.

4) N. Kohda: Kaitei-Kinzokubutsurigakujoron, (CORONA PUBLISH ING CO., LTD., Tokyo, 1973) p. 102.

5) T. Sukawa and M. Iguchi: Tetsu-to-Hagané 90 (2004) 334-338.

6) K. Mori: Tetsu-to-Hagané 77(1991) 2077-2083.

7) H. Kasahara and S. Taniguchi: J. Cryo. Soc., Jpn. 43(2008) 2-6.

8) T. Weier, J. Hüller, G. Gerbeth and F.-P. Weiss: Chem. Eng. Sci. 60 (2005) 293-298.

9) T. Yamada, M. Tsutsui, K. Itani and S. Asai: J. Japan Inst. Met. Mater. 58(1994) 1044-1049.

10) Y. Miki: Bull. Iron Steel Inst. Jpn. 19 (2014) 482-489.

11) T. Kawamura, K. Ito, T. Sakai, M. Nakajima, K. Fujiwara and H. Ohshima: Transactions of the Atomic Energy Society of Japan 7 (2008) 297-307.

12) S. Taniguchi and J. Yagi: Zairyoukougaku-no-tameno-Idousokudoron, (Tohoku University Press, Sendai, 2001) pp. 43-47.

13) The Chemical Society of Japan: The Fifth Series of Experimental Chemistry, Vol. 3, Fundamentals 3, (Maruzen, Tokyo, 2003) p. 136.

14) The Chemical Society of Japan: Handbook of Chemistry: Pure Chemistry, 3rd ed. (Maruzen, Tokyo, 1984) p. 3.

15) The Japan Institute of Metals and Materials: Kaitei 4Han Kinzokudata-book, (Maruzen, Tokyo, 2004) pp. 4-10.

16) T. Yokota, A. Maruyama, T. Yamada and K. Iwai: Tetsu-to-Hagane 102(2016) $119-126$.

17) P. G. Drazin: Journal of Fluid Mech. 4(1958) 214-224. 